\title{
Mark Tulij Cicero: Scipionove sanje
}

\author{
Prevod Barbara Zlobec Del Vecchio
}

Scipionove sanje (Somnium Scipionis) so daljši odlomek iz zadnje, šeste knjige obširnega spisa De re publica. Delo je napisano v obliki dialoga, ki naj bi potekal leta 129 pr. Kr. med Scipionom Emilijanom in njegovimi učenimi prijatelji. V njem Cicero analizira rimske politične institucije in razmišlja o različnih državnih sistemih ter o cikličnih spremembah, vzponih in padcih človeških združb. Na podlagi teh razmišljanj in lastnih političnih izkušenj izriše figuro idealnega državnika: njegov princeps je vzor etičnih vrlin, ki so dediščina veličastne preteklosti. De re publica je torej hvalnica rimski republikanski tradiciji, zato ni čudno, da je že v prvi fazi principata veljala za »nevarno« čtivo; delo so prebirali le redki učenjaki in naposled se je za njim izgubila vsaka sled, dokler ni Angelo Mai leta 1819 odkril nekaj daljših odlomkov v palimpsestu, ki se je ohranil v samostanu svetega Kolumbana (Vat. Lat. 5757). Sam Somnium Scipionis, izbrušen in pomensko nabit Scipionov samogovor, s katerim je Cicero zaključil in podkrepil spis De re publica, pa se je zaradi eshatološkega in mističnega sporočila o nebeških nagradah, ki jih bodo v posmrtnem življenju deležni pravičniki, ohranil kot samostojno sklenjeno besedilo in nadaljeval svojo potovanje v krščanski srednji vek. Glavni vzor za Cicerona je bila Platonova Politeia (Država), specifična za Somnium Scipionis pa je zgodba o Eru, ki naj bi mu bilo dovoljeno vrniti se $v$ življenje in razkriti, kaj je videl $v$ onostranstvu. Scipion pripoveduje o preroških sanjah, ki jih je bil doživel dvajset let prej (leta 149 pr. Kr.), ko ga je med tretjo punsko vojno gostil numidijski kralj Masinisa. Eshatološka vizija nagrad, ki jih bodo deležni vsi, ki so svoje življenje zastavili v prid države, se v obliki Ringkomposition navezuje na proemij De re publica (1.7.12), kjer je Cicero izrazil misel, da se ljudje še najbolj približajo bogovom, ko ustvarjajo oziroma ohranjajo človeške skupnosti. 


\section{SREČANJE MED SCIPIONOM IN MASINISO}

1 (9) Ko sem dospel ${ }^{1}$ v Afriko ${ }^{2}$ - kot veste, sem bil dodeljen konzulu Maniju Maniliju ${ }^{3}$ in imenovan za vojaškega tribuna četrte legije -, se mi nič ni zdelo pomembnejše od srečanja z Masiniso, ${ }^{4}$ kraljem, ki je bil po pravici zelo drag prijatelj naše družine. Komaj sem stopil predenj, ${ }^{5}$ me je starec objel, planil v jok in malo zatem dvignil pogled v nebo ter dejal: »Hvaležen sem ti, prevzvišeno Sonce, ${ }^{6}$ in vam, ostala nebeška božanstva, da smem, preden zapustim to življenje, ${ }^{7}$ videti v svojem kraljestvu in pod to streho Publija Kornelija Scipiona; meni že samó njegovo ime ${ }^{8}$ vliva novih moči: do te mere je v mojem srcu zakoreninjen spomin na tistega izjemnega in resnično nepremagljivega moža. « Nato sem ga jaz začel spraševati o njegovem kraljestvu, on pa mene o naši republiki in tako nama je ob vzajemnem klepetu minil dan.

\section{SCIPIONOVE SANJE}

(10) Potem ko so nam izrekli dobrodošlico s sijajno gostijo, smo pozno v noč nadaljevali s pogovorom; starec vtem ni govoril o ničemer drugem kot o Afričanu in se ni spominjal le vseh njegovih podvigov, ampak tudi njegovih besed. Ko smo se nato odpravili spat, sem potonil v globlje spanje kot običajno, saj sem bil izmučen od potovanja in od bedenja, ki se je bilo zavleklo dolgo v noč.

1 Scipion se obrača na sogovornike dialoga De re publica. Njegova veličastna figura daje odlomku posebno slovesnost; o karizmatičnosti tega vojaškega in političnega vodje, ki so mu pripisovali celo dar preroštva, pričajo številni zgodovinski viri, npr. Livij (26.19.4-5), Gelij (6.1), Enij (frag. varia 23 isl. $V^{2}$ ), Seneka (Ep. 108.34). Prim. Roberta Montanari Caldini, Tradizione medievale ed edizione critica del Somnium Scipionis (Firence: SISMEL-Edizioni del Galluzzo, 2002), 469-472.

2 Scipion Emilijan je v Afriko dospel leta 149 pr. Kr., da bi se udeležil tretje punske vojne, ki se je zaključila tri leta pozneje s padcem Kartagine. Scipion je bil tedaj star šestintrideset let.

3 Rimski vojski sta načelovala konzula Manij Manilij in Lucij Marcij Cenzorin; Manilij, ki je med drugim eden izmed sogovornikov v delu De re publica, je brez pravih uspehov vodil kopenske čete bodisi tistega leta bodisi naslednje kot prokonzul; večjo slavo si je pridobil kot jurist.

4 Masinisa, kralj Numidije (današnji Tunizija in Alžirija), je v prvi fazi druge punske vojne podpiral Kartažane, nato pa je prestopil na stran Rimljanov. Ti so mu pomagali premagati Sifaksa, kralja zahodne Numidije, in mu omogočili, da si je podvrgel celotno pokrajino. Masinisa pa je s svojo konjenico bistveno pripomogel k zmagi, ki jo je izvojeval Scipion Afričan nad Hanibalom pri Zami leta 202 pr. Kr. V času Emilijanovega obiska naj bi bil star že enaindevetdeset let; umrl je naslednje leto.

5 Zgodovinarji so mnenja, da je srečanje, ki ga opisuje Cicero, izmišljeno. Scipion naj bi Masiniso prvič srečal že leta 151. Tedaj ga je zaprosil za slone, ki naj bi se jih poslužili v vojni v Hispaniji. K numidijskemu kralju naj bi bil namenjen tudi leta 148, a ko je dospel v prestolnico Cirto, je izvedel, da je bil starec že umrl.

6 Številna ljudstva na Vzhodu so častila sonce kot najvišje božanstvo. Sami Numidijci so bili mnenja, da izhajajo iz Perzijcev, od katerih naj bi prevzeli ta kult.

7 V izvirniku migro: dobesedno "se odselim«, saj za Masiniso smrt ni nič drugega kot selitev z

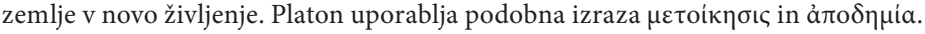

8 Ded in vnuk sta nosila isto ime (Publij Kornelij Scipion), zato se Masinisi zdi, da ima pred seboj starega zaveznika Publija Kornelija Scipiona Afričana, zmagovalca pri Zami. Dejansko pa je Afričan samo posinovil Lucija Emilija Pavla, zmagovalca pri Pidni, zato je njegov sin dobil ime po zmagovalcu nad Hanibalom. 
Tedaj se mi je prikazal Afričan, takšen, kakršnega sem poznal bolj po portretu ${ }^{9}$ kot iz osebne izkušnje (mislim, da se je to vsekakor zgodilo zato, ker smo se bili pogovarjali o njem; pogosto se namreč dogaja, da naše misli in razgovori med spanjem rodijo doživetje, podobno tistemu, ki ga Enij omenja v zvezi s Homerjem, ${ }^{10}$ o katerem je očitno v budnem stanju imel navado zelo pogosto razmišljati in razpravljati). ${ }^{11}$ Komaj sem ga prepoznal, me je spreletela mrzla zona, on pa je rekel: »Pomiri se in se premagaj, Scipion, ter si zapomni, kar ti bom povedal.«

\section{PREROKBA}

2 (11) »Ali vidiš tisto mesto, ki sem ga jaz prisilil, da se je pokorilo rimskemu narodu? Sedaj obnavlja boje iz preteklosti in ne more živeti v miru (kazal je namreč proti Kartagini z nekega visokega, z zvezdami pretkanega, svetlega in jasnega kraja). Ti se mu sedaj približuješ, da bi ga napadel, skoraj kot navaden vojak, ${ }^{12}$ a čez dve leti ga boš zavzel kot konzul ${ }^{13}$ in si boš sam, zaradi svojih zaslug, pridobil tisti vzdevek, ki ga trenutno imaš zato, ker si ga podedoval od mene. ${ }^{14}$ Potem ko pa boš porušil Kartagino, boš slavil triumf in boš imenovan za cenzorja ter boš kot legat prepotoval Egipt, Sirijo, Malo Azijo in Grčijo; ${ }^{15}$ med tvojo odsotnostjo te bodo ponovno izvolili za konzula in napravil boš konec zelo pomembni vojni: porušil boš Numancijo. ${ }^{16}$ Ko pa se boš na triumfalnem vozu peljal na Kapitol, boš v domovini priča razdorov, ki jih bo sejal moj vnuk. ${ }^{17}$

(12) Tedaj, Afričan, bo potrebno, da domovini zasveti luč tvojega poguma, razuma in modrosti. Vnaprej vidim, da se v tistih okoliščinah, da se tako izra-

9 Ko je Scipion Afričan umrl, je bil Emilijan star komaj dve leti. Njegova zunanjost mu je bila torej znana le prek voščene maske prednika (imago), ki je po tradiciji krasila hišni atrij skupaj z drugimi podobami uglednih prednikov.

10 Cicero se navezuje na odlomek iz proemija Enijevih Analov (fr. 2-3 Skutch: somno leni placidoque revinctus ... visus Homerus adesse poeta), v katerem arhaični rimski pesnik opisuje, kako se je v sanjah pogovarjal s svojim pesniškim vzorom Homerjem. Ta mu je zaupal, da je Enij njegova reinkarnacija. Motiv, ki izhaja iz pitagorejskega nauka o metempsihozi, je topičen. Navajanje Enija po vsej verjetnosti ni slučajno, saj je bil ta tesno povezan s krožkom Scipionov in je z izjavo, da je rimski Homer, izpolnjeval njihov politično-kulturni program.

11 Racionalno razlago sanj srečamo že pri filozofu Empedoklu (fr. 31 B 108 DK), pa tudi pri zgodovinarju Herodotu (7.16.2), pri Aristotelu (Somn. $460 \mathrm{~b} 28$ isl.) ter pri samem Ciceronu (Div. 2.62.128).

12 Emilijan je v vojski dosegel naziv tribunus militum in je bil torej le za en čin višji od preprostih vojakov.

13 Emilijan je konzulski naslov dosegel v letih 147 in 134. Prvič je postal konzul v starosti osemintrideset let, to je pred predpisano starostjo, ki jo je predvidevala lex Villia annalis (43 let). Drugič ni vložil kandidature, a ga je ljudstvo kljub temu soglasno izvolilo.

14 Gl. op. 8.

15 Za cenzorja je bil imenovan leta 142 . Kot poslanec je omenjene pokrajine prepotoval v letih 140-139, da bi razrešil dinastične spore.

16 Prestolnico Keltiberov je Emilijan zavzel jeseni leta 133.

17 Afričan namiguje na agrarni zakon, ki ga je v času obleganja Numancije v Rimu predlagal njegov vnuk (sin hčerke Kornelije), Tiberij Grakh. 
zim, pot usode cepi: ${ }^{18}$ ko boš dosegel starost, ki odgovarja osemkrat opravljenim sedmim sončevim revolucijam, ${ }^{19}$ in ko bosta tidve števili, ki ju obe imamo za popolni iz različnih razlogov, ${ }^{20} \mathrm{v}$ naravnem poteku časa dali vsoto, ki bo zate usodna, se bodo vsi meščani priporočali samo tebi in tvojemu imenu, tebe bo pred očmi imel senat, tebe vsi poštenjaki, tebe zavezniki, tebe Latini, ti boš edini, na katerem bo slonela rešitev celega mesta; ${ }^{21}$ da ne izgubljam besed: potrebno bo, da kot diktator ${ }^{22}$ preustrojiš državo, če ti bo uspelo ubežati brezbožnim rokam sorodnikov.«

Ker se je tedaj Leliju ${ }^{23}$ izvil krik iz prsi in so ostali globoko zaječali, se je Scipion rahlo nasmehnil ${ }^{24}$ in rekel: »Pst! Ne zbudite me, prosim, iz sanj in sledite še malo moji pripovedi.

\section{POSMRTNO ŽIVLJENJE}

3 (13) Zato da boš odločneje branil državo, imej v mislih naslednje: vsem tistim, ki so varovali državo, jo podpirali in jo okrepili, je zagotovljen na nebu točno določen kraj, kjer blaženi uživajo večnost. Najvišjemu božanstvu, ki vlada vsemu svetu, ${ }^{25}$ namreč od vsega dogajanja na zemlji nič ni ljubše kot zveze in združbe ljudi, ki temeljijo na zakonih in ki jim pravimo mesta; voditelji in upravitelji le-teh izhajajo od tod in se sem povračajo."

(14) Čeprav sem bil prestrašen (strahu mi ni vzbujala toliko smrt kolikor zahrbtnost mojih sorodnikov), sem tedaj vseeno vprašal, ali so še živi on sam

18 Motiv poti, ki se cepi, je topičen (najslavnejši primer je »Herakles na razpotju«). Narekuje pa ga tudi verodostojnost pripovedi, saj Scipion ne bi mogel z gotovostjo poznati svoje usode.

19 To je 56 (8x7) sončnih let; to starost je Emilijan dejansko dosegel (185-129). Sedem je mistična številka, ker je rezultat triade in tetrade $(3+4)$, osem pa je prvo kubično število $(2 \times 2 \times 2)$; gl. tudi naslednjo opombo.

20 Teorijo o popolnosti nekaterih števil pripisujejo Pitagori, ki naj bi jo prevzel od Egipčanov (Diod. 1.98.2). Številka osem naj bi bila popolna (numerus plenus, gr. $\tau \dot{\imath} \lambda \varepsilon \iota \varsigma$ ), ker je bilo poznanih planetov osem. Popolno naj bi bilo tudi število sedem, in sicer zato, ker je vsota lihega in sodega števila. Makrobij je bil mnenja, da je po Ciceronu število let, ki jih je dosegel Emilijan, popolno, ker je zmnožek sode (ženske) številke 8 in lihe (moške) številke 7.

$21 \mathrm{~V}$ stavku tu eris unus in quo nitatur civitatis salus se verjetno skriva besedna igra $\mathrm{v}$ zvezi $\mathrm{z}$ imenom (cognomen) "Scipion«, ki so ga etimološko povezovali z besedo scipio, to je "palica«; nitor pa pomeni med drugim »opirati oz. naslanjati se«. Scipion Emilijan bo torej edina "palica«, na katero se bo lahko oprl Rim.

22 Scipion je leta 129 skušal zadušiti nemire, ki so jih zanetile debate o agrarnem zakonu. Ko bi moral pred ljudstvom ponoviti govor, ki ga je dan prej imel v senatu, je umrl v nepojasnjenih okoliščinah. Cicero trdi, da mu je ljudstvo ponovno namenilo diktaturo, vendar podatka ne potrjujejo drugi viri. Nekateri viri pa potrjujejo Ciceronovo domnevo, da so ga zastrupili Grakhovi privrženci, Scipionovi sorodniki.

23 Gaj Lelij, konzul leta 140, protagonist dela O prijateljstvu in eden izmed sogovornikov v dialogu De re publica, je bil Scipionov najboljši prijatelj in se je bil z njim udeležil pohoda proti Kartagini. Tu Scipionovo pripoved začasno prekine prestrašeni Lelijev krik.

24 Stoiški modrijan se ne boji smrti, ker ve, da ga v večnosti čaka novo življenje. Tudi Sokrat naj bi se, preden je izpil trobeliko, mirno nasmehnil (Plat., Phaed. 115c).

$25 \mathrm{~V}$ odlomku prevladuje monoteistična predstava o edinem božanstvu, ki izhaja iz platonske tradicije. Drugje je doživljanje božanskega obarvana bolj panteistično. 
in oče Pavel ${ }^{26}$ in drugi, za katere smo mislili, da so umrli. On je odgovoril: »Nasprotno, živi so tisti, ki so zleteli iz spon teles kot iz zapora, to pa, čemur pravite življenje, je smrt. ${ }^{27}$ Mar ne vidiš očeta Pavla, ki ti prihaja naproti? « ${ }^{28}$ Ko sem ga zagledal, se mi je iz oči res izlila reka solza, on pa me je objel in mi branil jokati.

(15) Ko mi je uspelo zadržati ihtenje in spregovoriti, sem dejal: »Najčastitljivejši, najboljši oče, če je pravo življenje tole, kot slišim trditi Afričana, zakaj se še obotavljam na zemlji? Zakaj ne pohitim sem k vam? « On je odvrnil: »Ni tako. Če te ne osvobodi telesnih spon tisti bog, ki mu pripada ves nebesni svod, ${ }^{29}$ ki ga imaš pred očmi, ti dostop v ta kraj ni dovoljen. ${ }^{30}$ Ljudje se namreč rodijo $\mathrm{z}$ nalogo, da obvarujejo oblo, ki jo vidiš na sredini nebesnega svoda ${ }^{31}$ in ki jo imenujemo zemlja; dodeljena jim je duša, ki izhaja iz večnih ognjev, ki jim pravite nebesna telesa in zvezde. ${ }^{32}$ Te ognje, ki imajo obliko okroglih gmot in ki jih usmerjajo božanski umi, opravljajo krožne poti po orbiti z občudovanja vredno hitrostjo. Ti, Publij, in vsi pobožni ljudje morate zato ohraniti dušo $\mathrm{v}$ ječi telesa ${ }^{33}$ in brez dovoljenja tistega, ki vam jo je dodelil, ne smete zapustiti življenja na zemlji, da se ne bi zdelo, da bežite pred človeško dolžnostjo, ki jo je naložil bog.

(16) Ti pa, Scipion, po zgledu tega svojega prednika in mene, ki sem te zaplodil, goji pravičnost in spoštovanje, ki sta sicer temeljni vrlini v odnosih s starši in sorodniki, sam vrh pa dosežeta v opravljanju dolžnosti v prid države. Takšno življenje je pot, ki vodi v nebo in v skupnost tistih, ki so že zaključili svojo

26 Lucij Emilij Pavel Makedonski, Scipionov sin, je naslov dobil zaradi zmage pri Pidni (168), s katero se je zaključila tretja makedonska vojna. Bil je sin konzula Emilija Pavla, ki je bil padel v bitki pri Kanah. Scipion ga je posvojil, da bi utrdil vezi med družinama.

27 To misel zagovarja filozof Heraklit (fr. 62 DK), metafora telesa, ki vklepa človeka kot v zapor, pa ima svoj izvir v Platonovi filozofiji (Phaed. 67d, Crat. 40oc, Gorg. 493a; prim. besedno igro $\sigma \tilde{\omega} \mu \alpha-\sigma \tilde{\eta} \mu \alpha$ : telo-grob).

28 Dialog doseže vrh patetičnosti ob prihodu Emilijanovega očeta. Pristop tretje osebe k pogovoru med nadzemskim srečanjem izhaja iz literarne tradicije. Tako se v 11. knjigi Odiseje Tejreziji in Odiseju pridruži mati grškega bojevnika; podobno se tudi v 6. knjigi Eneide pogovarjajo Enej, Sibila in Anhiz.

29 Izraz templum v tem primeru ne pomeni »svetišče«, temveč »del neba«. Gre za sakralen izraz, ki je etimološko blizu grškemu $\tau \dot{\varepsilon} \mu \varepsilon v o \varsigma$ ( $\tau \dot{\varepsilon} \mu \nu \omega$, režem) in pomeni "prostor, določen in posvečen božanstvu«.

30 Zavračanje samomora kot rešitve iz življenjske stiske izhaja iz tradicije stoiške filozofije. Ta motiv srečamo v Platonovem Fajdonu (Phaed. 61d-62c): Sokrat je prepričan, da mora človek do konca izpolniti usodo, ki so mu jo namenili bogovi. Podobno trditev je Cicero pripisal Pitagori $\mathrm{v}$ delu Cato maior de senectute (20.73).

$31 \mathrm{Ni}$ presenetljivo, da pri Ciceronu prevlada geocentrična teorija, ki jo v antiki srečujemo od Anaksimandra do Platona (Tim. 38d, Phaed. 108e) in Aristotela (Cael. 296a). Ta teorija je namreč prevladovala vse do 16. stoletja, čeprav sta Aristarh s Samosa in Selevk iz Selevkije že v helenistični dobi skušala $\mathrm{z}$ matematičnimi izračuni dokazati heliocentrično teorijo.

32 Pojmovanje, da je izvor duše zvezdnato nebo, izhaja iz pitagorejske in platonske tradicije (Tim. 39 b isl., 42b isl.). Da je njena izvorna narava ognjena, je trditev, ki temelji na stoiškem nauku (Cic. Tusc. 1.19) in ki je bila splošno sprejeta v antični književnosti.

33 Izraz custodia pomeni bodisi »ječa« bodisi »stražno mesto«, ki ga vojak ne sme zapustiti vse do konca svoje službe. 
življenjsko izkušnjo na zemlji in živijo, odkar so se osvobodili teže telesa, na kraju, ki ga vidiš (šlo je za krog, ki se je med nebesnimi zublji bleščal v slepeči belini). Vi mu, kot ste se naučili od Grkov, pravite Mlečna cesta. «34

Meni, ki sem se razgledoval od tam, se je vse zdelo krasno in čudovito. Vidne so bile tudi tiste zvezde, ki jih z zemlje nikoli ne opazimo, in ogromnost vseh nebesnih teles je krepko presegala vse naše predstave. Med njimi je bilo najmanjše tisto, ki je najbolj oddaljeno od nebesnega svoda in najbližje zemlji ter se blešči od tuje svetlobe. ${ }^{35}$ Obseg zvezd je nadalje zelo prekašal zemeljskega po velikosti. Sama zemlja se mi je zazdela celo tako majhna, da sem se sramoval naših posesti, s katerimi zasedamo tako rekoč samo točko le-te.

\section{SESTAV VESOLJA}

4 (17) Ker sem zemljo opazoval z vse večjim zanimanjem, mi je Afričan dejal: »Prosim te, do kdaj bo tvoja pozornost usmerjena v tla? ${ }^{36}$ Ali se ne zavedaš, $v$ katere nebeške prostore si dospel? Pred sabo imaš vsemirje, združeno v devetih krogih, oziroma točneje sferah, od katerih je ena, najbolj zunanja, nebesna; ta zaobjema vse ostale in je najvišje božanstvo samo, ki obsega in združuje druge. Nanjo so pritrjene orbite, po katerih večno krožijo zvezde; pod njo leži sedem sfer, ki se vrtijo v nasprotno smer, ${ }^{37} \mathrm{z}$ gibanjem, ki nasprotuje gibanju neba. ${ }^{38}$ Eno izmed teh zaseda planet, ki mu na Zemlji pravijo Saturn. Sledi žareče telo, ki je ime dobilo po Jupitru; to je človeškemu rodu naklonjeno ${ }^{39}$ in mu prinaša blaginjo. Za njim je rdečkast in za zemljo razdiralen planet, ki mu pravite Mars. Sonce, vodja, vladar in urejevalec ostalih zvezd, ${ }^{40}$ razum in mera vsemirja, pa obsega skoraj osrednje območje spodaj; njegova velikost je toli-

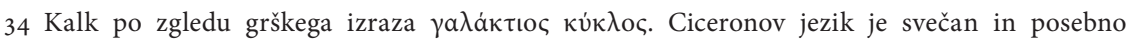
antično patino mu dajejo izbrane in antične besede (prim. Grai namesto utečenega Graeci, nuncupare itd.). Prepričanje, da se duše dobrih po smrti preselijo na Mlečno cesto, izhaja iz nauka pitagorejcev (Plat. Phaedr. 247b). S temi besedami se zaključi govor Emilija Pavla, ki nepričakovano in neslišno zapusti sceno.

35 Teorijo, da se luna sveti zaradi odseva sončeve svetlobe, so v antiki pripisovali Talesu iz Mileta, začetniku jonske naravoslovne filozofije.

36 Emilijan je razpet med zemeljskim in absolutnim, med sedanjostjo in preteklostjo, Afričan pa je ločitev že presegel in je kot duh povsem prost zemeljskih spon človeških strasti in želja.

$37 \mathrm{~V}$ antiki so menili, da se zvezde stalnice vrtijo od vzhoda proti zahodu, planeti pa v nasprotno smer.

38 Ciceronova vizija vesolja je odraz helenističnih prikazov, kakršne so ponazarjali antični planetariji, npr. Arhimedov, ki so ga po zavzetju Sirakuz prenesli v Rim (gl. Rep. 1.14.21-22). Vsemirje sestavlja devet koncentričnih sfer; zunanja, ki vsebuje zvezde stalnice, odgovarja samemu božanstvu, ki ureja nebo. Pod njo se nahajajo sfere Saturna, Jupitra, Marsa, Sonca, Venere, Merkurja, Lune in Zemlje, pri čemer omenjeni vrstni red ne izhaja iz egiptovske tradicije, ki ji sledita Platon (Tim. 38c-d) in Aristotel, temveč iz kaldejske tradicije (prim. Cic., Div. 2.43.91). Najnižja, zemeljska sfera, je nepremična in se nahaja na sredini vsemirja.

39 Po paretimologiji naj bi bil Jupitrovo ime izhajalo iz glagola iuvare "pomagati«.

40 Epiteti se navezujejo na mistični heliocentrizem, značilen za pitagorejstvo. Vlogo "uravnoveševalca«, ki naj bi jo imelo Sonce, Cicero razlaga z astronomsko-metereološkega vidika (Tusc. 1.68): z menjavanjem dneva in noči ter letnih časov sonce omogoča naravi pravilno ravnovesje. 
kšna, da s svojo svetlobo razsvetljuje in zapolnjuje vse. Temu kot sopotnika ${ }^{41}$ sledita vsak po svoji orbiti Venera in Merkur, v najnižji sferi pa kroži Luna, ki plamti od sončnih žarkov. Nižje pa ni več ničesar, kar ne bi bilo umrljivo in minljivo, razen duš, ki so jih bogovi poklonili v dar človeškemu rodu; nad Luno pa je vse večno. Deveta sfera, ki se nahaja na sredini, to je Zemlja, je namreč nepremična in zaseda najnižje območje; vse, kar je težko, se usmerja nanjo po lastnem nagibu.«

5 (18) Razlagi sem sledil z velikim občudovanjem, in ko sem si opomogel od začudenja, sem vprašal: »Kaj je to, kaj je ta glasni in nadvse prijetni zvok, ki mi polni ušesa?« On je odgovoril: »To je zvok, ki izzveni iz akorda sicer neenakih intervalov, ki pa so odbrani v skladu $\mathrm{z}$ racionalnimi razmerji; ${ }^{42}$ sproža ga vzgonska sila samih sfer. Z usklajevanjem nizkih in visokih tonov enakomerno ustvarja raznovrstne harmonije. ${ }^{43}$ Tako ogromno premikanje se namreč ne more vršiti v tišini in sama narava veleva, da se najbolj oddaljena konca vsemirja oglašata $\mathrm{z}$ ene strani $\mathrm{z}$ nizkim, $\mathrm{z}$ druge $\mathrm{pa} \mathrm{z}$ visokim zvenom. Iz tega vzroka se najvišji nebesni krog, ki nosi zvezde, premika $z$ visokim in zvonkim zvokom, ker je njegovo kroženje hitrejše, Lunin pa, ki se nahaja najnižje, z zelo globokim. Deveta sfera, Zemlja, ki stoji negibno, je namreč pričvrščena vedno na isto mesto in zaobjema osrednji del vsemirja. Nasprotno tistih osem orbit, med katerimi imata dve isto hitrost, ${ }^{44}$ ustvarja sedem tonov $\mathrm{z}$ različnimi intervali; to število je tako rekoč vozlišče vseh stvari. ${ }^{45}$ Modrijani, ${ }^{46} \mathrm{ki}$ so posnemali to harmoničnost $\mathrm{z}$ brenkali in s petjem, ${ }^{47}$ so si odprli pot v ta kraj, kot tudi drugi, ki so se z izjemno nadarjenostjo v svojem zemeljskem življenju posvečali preučevanju božjega.

41 Spremljevalca (comites) Venera in Merkur stojita ob strani kralju (princeps) Soncu; termin comes naj bi izhajal iz političnega jezika. Astronomska razlaga naj bi torej odsevala politično pojmovanje družbe, v kateri so višji sloji vodilni, nižji pa se jim pokoravajo.

42 Matematična razmerja, ki naj bi urejala premikanje planetov ter oddajanje visokih oziroma nizkih zvokov, in sicer v različnih intervalih glede na hitrost premikanja, so preučevali pitagorejci. Ujemanje in spojitev vseh zvokov naj bi porodila nebeško harmonijo: ta izraz je Cicero prevzel od pitagorejcev in ga prevedel $\mathrm{s}$ terminom concentus. Motiv srečamo v Platonovem mitu o Eru (Rep. 614a-621d).

43 Morda še en politični namig: vsi družbeni sloji pod vodstvom plemenitih voditeljev ustvarijo harmonijo v državi.

44 Isto hitrost imata Venera in Merkur.

45 Gl. zgoraj, op. 19 in 20.

46 Po razširjeni pitagorejski teoriji, ki temelji tudi na mitološkem izročilu (Apolon je bog sonca, pa tudi glasbe), naj bi glasbena praksa izhajala iz kozmične harmonije. Gre za literarni motiv, ki ga je razvil zlasti aleksandrinski učenjak Eratosten v delu Hermes (fr. 15 Hiller), srečamo pa ga tudi pri Varonu, ki v Menipejskih satirah (fr. 351 Astbury) kozmos imenuje »lira bogov«. Nekateri komentatorji opozarjajo, da Cicero v tem odlomku predvideva posmrtno življenje na Mlečni cesti za tiste modrijane (docti homines), ki so v antiki veljali za stvaritelje glasbe (torej Orfej, Lin, Terpander itd.), ter za preučevalce božanskega, medtem ko je prej ta privilegij povezoval (gl. 4.16) s političnim življenjem. Res pa je, da je v zaključnem delu (9.29) pojasnil, da se vse duše prej ali slej vrnejo v nebo, hitrost vrnitve pa odvisi od njihove moralne drže in njihovih zaslug.

47 Nekateri razlagalci izraz nervis ... cantibus pojmujejo kot hendiado in prevajajo "z glasbo na brenkala «. 
(19) Ljudje, ki jim je to zvenenje polnilo ušesa, so oglušeli; ${ }^{48}$ in res ni čuta, ki bi bil pri vas šibkejši. Podobno je tudi v pokrajini, ki se imenuje Katadupa, ${ }^{49}$ kjer se Nil strmo spušča $\mathrm{z}$ najvišjih gora, tamkajšnje ljudstvo izgubilo sluh zaradi mogočnega šumenja reke. Tudi zvenenje, ki ga povzroča izredno naglo kroženje celotnega vsemirja, je tako močno, da ga človeška ušesa ne morejo zaznati, podobno kot ni možno strmeti naravnost v sonce, sicer vam njegovi žarki izničijo sposobnost gledanja.«

\section{OMEJENOST ČLOVEŠKE SLAVE}

6 (20) Vse to mi je vzbujalo veliko občudovanje, vendar mi je pogled vseeno pogosto uhajal proti zemlji. Tedaj je Afričan dejal: »Opažam, da si še vedno ogleduješ bivališče in domovino ljudi; če se ti zdi majhna, kot dejansko res je, usmerjaj vedno svoj pogled v nebeški svod in se ne meni za človeške zadeve! Ali smeš upati, da te bodo ljudje omenjali v svojih pogovorih? Kakšno slavo lahko dosežeš, ki bi bila vredna, da si jo želiš? Saj vidiš, da so na zemlji naseljeni le redki in ozki pasovi ter da se med samimi - da se tako izrazim - pegami, ${ }^{50}$ ki so obljudene, širijo ogromne pustinje! Tisti, ki naseljujejo zemljo, niso samo med sabo tako oddaljeni, da so med enimi in drugimi stiki onemogočeni, ampak tudi živijo $\mathrm{v}$ pokrajinah, ki se nahajajo $\mathrm{v}$ primerjavi $\mathrm{z}$ vašo deloma poševno, deloma prečno in deloma celo na antipodih. ${ }^{51}$ Od njih si gotovo ne morete pričakovati slave! $!^{52}$

(21) Opažaš nadalje, da je taista zemlja tako rekoč ovenčana in obdana s pasovi, ${ }^{53}$ od katerih sta dva, ki sta med seboj najbolj oddaljena in se na vsaki strani naslanjata na sama tečaja, kot vidiš, otrpnila zaradi ledu, osrednji pas pa je razpaljen od sončne pripeke. ${ }^{54} \mathrm{Za}$ bivanje sta primerna dva pasova: prvi

48 Aristotel (Cael. 2.9.29ob) je menil, da ljudje ne morejo slišati zvoka, ki ga povzročajo planeti, v kolikor je bil ta prisoten še pred njihovim rojstvom.

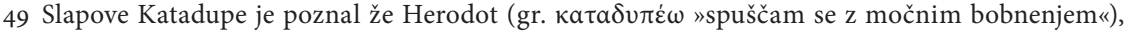
omenja pa jih tudi Seneka v delu Naturales quaestiones (4.2.5).

$50 \mathrm{~V}$ vsej latinski književnosti se termin macula v geografskem smislu (»neznaten predel«) pojavlja samo v tem Ciceronovem odlomku (verjetno gre za kalk grške besede $\sigma \pi i \lambda$ oৎ). Beseda nazorno prikazuje kopico med seboj oddaljenih obljudenih pokrajin, ki jih sogovornika imata pred očmi.

51 Obliqui so tisti, ki živijo na našem poldnevniku, a na drugi (južni) polobli; transversi živijo na našem vzporedniku, vendar na nasprotnem poldnevniku; adversi pa na nasprotnem poldnevniku na drugi polobli.

52 Motiv ničnosti človeške slave (vanitas gloriae) je obravnaval že Aristotel v izgubljenem Protreptiku. K tej temi se je Cicero vrnil tako v izgubljenem Hortenziju kot v Razpravah $v$ Tuskulu.

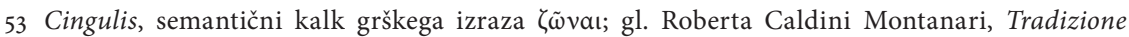
medievale ed edizione critica del Somnium Scipionis (Firence: SISMEL-Edizioni del Galluzzo, 2002), 518.

54 Cicero sledi ustaljeni tradiciji, ki sega od Parmenida, ustanovitelja filozofske šole eleatov (fr. 28 B 44a DK), prek Aristotela do rimske priročniške geografije (Chorographia Varona iz Ataksa, fr. 16, 1 M.). Ta je trdila, da se zemlja deli na pet pasov: enega vročega, dva zmerna in dva mrzla (odmev teh teorij srečamo v latinski poeziji: Lucr. 5.195-234, Verg., Georg. 1.232 isl., Ov., Met. 1.45 
je južni, v katerem prebivalci ubirajo stopinje po vam diametralno nasprotni površini, in ta nima nič skupnega $z$ vašimi ljudmi; glede drugega pa, ki je izpostavljen burji in ki ga naseljujete, glej, kako skromen je del, ki vam pripada. Vse področje namreč, ki je vaš dom, je v bistvu majhen otok, zožen na vrhovih in širši na straneh, ki ga obdaja ono morje, ki ga na zemlji imenujete Atlantik, Veliko morje, Ocean, ${ }^{55}$ a vendar vidiš, kako je majhno kljub visokodonečemu imenu.

(22) Je mar iz teh obljudenih in znanih pokrajin tvoje ime ali ime kogarkoli izmed nas zmoglo prekoračiti ta Kavkaz, ki ga vidiš, ali preplavati oni Ganges? ${ }^{56}$ Kdo bo v ostalih oddaljenih območjih na vzhodu ali na zahodu, na severu ali na jugu ${ }^{57}$ izvedel za tvoje ime? Če izključiš te pokrajine, ti je takoj jasno, v kako ozkih mejah bi se hotela širiti vaša slava. In tudi tisti, ki govorijo o nas, kako dolgo bodo o nas še govorili?

7 (23) Pa tudi če bodo prihodnje generacije želele posredovati še naprej potomcem slavospev vsakogar izmed nas, ki so ga podedovale od očetov, si vendar zaradi poplav in požarov, ki se nujno pojavljajo v določenih presledkih, ${ }^{58}$ ne moremo zagotoviti dolgotrajne, kaj šele večne slave. Kaj ti je končno mar, da govorijo o tebi tisti, ki se bodo rodili po tebi, če o tebi niso govorili tisti, ki so se rodili pred teboj?

(24) Ti niso bili manj številni, gotovo pa so bili boljši možje; ${ }^{59}$ povedano velja toliko bolj, ker nihče od tistih, ki so lahko izvedeli za naše ime, le-tega ne bo mogel obdržati v spominu več kot eno leto. Ljudje namreč običajno merijo leto na podlagi revolucije Sonca, to je ene same zvezde; ko pa se vse zvezde povrnejo tja, od koder so nekoč začele svojo pot, in po dolgem presledku ponovno zavzamejo isti položaj, tedaj se sme res trditi, da je šlo leto naokrog; težko bi rekel, koliko človeških stoletij bi zaobjemalo! ${ }^{60}$ Kot se je namreč nekoč ljudem zdelo, da je sonce izginilo in ugasnilo, ko je Romulov duh dospel prav $\mathrm{v}$ te nebesne prostore, ${ }^{61}$ tako se bo tedaj, ko bo ponovno na istem delu neba in

isl.). Slavni stoik Pozejdonij iz Apameje je nasprotno menil, da je pasov sedem.

55 Tudi predstava, da je zemlja velik otok, ki ga obdaja Ocean, verjetno izhaja iz Eratostena, ki jo je prikazal kot $\chi \lambda \alpha \mu i$ ç oziroma plašč, ki je širok na sredini in se oži na koncih (Strab. 2.5.14). Izraz Atlantik je učen (uporabljal ga je že Eratosten) in pesniški, Ocean pa splošnejši in bolj razširjen.

56 Cicero imenuje kraja na skrajnem severovzhodu in jugovzhodu tedaj znanega sveta.

57 Veter aquilo piha s severovzhoda, auster pa z juga.

58 Cicero se navezuje na stoiško teorijo o prenovi sveta, ki naj bi jo povzročili ciklični poplave in

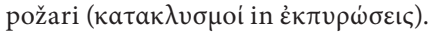

$59 \mathrm{Ni}$ jasno, ali se te besede nanašajo na Rimljane, ki so živeli v arhaični dobi, ali pa zadevajo mitično zlato dobo.

6o Kozmično leto (annus magnus) je stoična hipoteza, ki jo srečamo npr. v Platonovem Timaju (Tim. 39d), ki ga je Cicero prevedel. Po Ciceronu naj bi zajemalo 12.954 sončnih let (Hortensius fr. 54 M., prim. Tac., Dial. 16.7). Od Romulove smrti (tradicionalno 716 pr. Kr.) do dogajanja, ki ga opisujejo Scipionove sanje (149 pr. Kr.), je prešlo 567 let, kar dejansko znese nekaj manj kot dvajsetino Ciceronovega kozmičnega leta.

61 Sončev mrk, ki je sovpadal z Romulovim izginotjem (716 pr. Kr.), pomeni Ciceronu začetek 
v istem času sončev mrk in ko se bodo vsa ozvezdja in zvezde vrnila na izvorno točko, leto izteklo; vsekakor pa vedi, da se še ni iztekla niti dvajsetina tega kozmičnega leta.

(25) Če bi ti torej izgubil upanje na povratek v ta kraj, ki velikim in izjemnim možem pomeni vse, kakšno vrednost bi sploh imela človeška slava, ki lahko traja komaj delček enega leta? Če nameravaš dvigniti pogled in opazovati to bivališče, večno domovino, se zato ne prepuščaj ljudskemu glasu in ne vdajaj se upanju, da boš za svoje zasluge prejel nagrado od sočloveka. Potrebno je, da te sama krepost s svojo privlačnostjo usmerja k resnični časti. Kaj drugi govorijo o tebi, je njihova stvar; govorili bodo vsekakor. Vsako tako govorjenje je vsekakor omejeno na one ozke meje pokrajin, ki jih vidiš, in nihče nikoli ni užil večne slave, saj besede pokopljejo z ljudmi in jih ugasne pozaba potomcev.«

\section{BOŽANSKOST DUŠE}

8 (26) Na te besede sem odgovoril: »Afričan, če je za tiste, ki so bili zaslužni do domovine, res odprta nekakšna pot $^{62}$ za vstop v nebo, se bom jaz osebno, čeprav sem že od mladih nog stopal po očetovih in tvojih stopinjah ter se nisem izneveril vajinemu dostojanstvu, sedaj, ko si mi razkril tolikšno povračilo, trudil z veliko večjo vnemo. «On pa je rekel: »Ti se res trudi in bodi prepričan, ${ }^{63}$ da nisi umrljiv ti, pač pa to telo; nisi namreč takšen, kakršnega te razkriva zunanja podoba: pravo bistvo vsakogar je um, ne pa tista zunanja podoba, ki jo lahko pokažemo s prstom. ${ }^{64}$ Vedi torej, da si bog, ${ }^{65}$ če je res bog tisti, ki je živ, ki občuti, ki se spominja, ki vidi naprej, ki tako vodi in upravlja in premika tisto telo, ki mu je bilo dodeljeno v upravljanje, kot ureja ta svet ono najvišje božanstvo; kot sam večni bog poganja svet, ki je delno umrljiv, tako neminljiva duša premika krhko telo.

(27) Kar se namreč vedno giba, je večno; kar pa sproža premikanje nečesa, a sámo črpa gonilno silo drugje, nujno neha bivati, ko le-ta preneha. Samo tisto,

kozmičnega leta, v katerem se je sam rodil in ki naj bi trajalo še veliko stoletij.

62 Pot za vstop v nebo (limes ad caeli aditum) je očitno že omenjena via ... in caelum (3.16), vendar je Cicero z agrarnim terminom limes (»poljska steza«) hotel poudariti, da pot do cilja, to je do Mlečne ceste, ni zglajena, pač pa naporna in polna ovir.

63 Še en imperativ futura (habeto), ki poudarja slovesnost trenutka in večno veljavo napotkov. Karl Büchner v komentarju k delu Cicero, De re publica (Heidelberg, 1984), 498, zagovarja hipotezo, da je zadnji del Scipionovih sanj sklep filozofskega prikaza pitagorejsko-platonistične misli, ki jo je avtor podal v dialogu. Drugi interpreti so povečini mnenja, da je teorija o duši temeljnega pomena za razumevanje celotnega besedila.

64 Misel izhaja iz orfično-pitagorejske tradicije, v rimsko filozofijo pa je prešla prek Platonovega posredovanja (prim. Leg. 959b).

$65 \mathrm{~V}$ delu Tusculanae disputationes (1.26.65) se je Cicero izrazil previdneje, češ da je duša božanskega izvora, in enačenje med bogom in dušo pripisal »drznemu« tragiku Evripidu (fr. 1007 Nauck). 
kar ima gonilno silo v sebi, se torej nikoli ne neha gibati, saj ne more zapustiti samega sebe; nasprotno, tudi za vse ostalo, kar se premika, je to izvor in počelo gibanja. ${ }^{66}$ Počelo pa nima nobenega izvora; iz počela namreč izvira vse, sámo pa ne more nastati iz ničesar drugega; kar bi namreč imelo izvor drugje, ne bi moglo biti počelo; če pa nekaj nikoli ne nastane, niti nikoli ne izgine. Izničeno počelo namreč niti ne bi moglo ponovno nastati iz česa drugega niti ne bi moglo ustvariti česa drugega iz sebe, če je pač potrebno, da ima v počelu vse svoj izvor. Zato ima premikanje izvor v tistem, kar je sámo vzrok svojega gibanja, to pa ne more niti nastati niti se izničiti, sicer bi bilo nujno, da bi se nebo zrušilo in bi se vsa narava ustavila, saj ne bi imela nobene gonilne sile, ki bi sprožila njeno premikanje.

9 (28) Ker je torej očitno, da je večno to, kar ima v sebi gonilno silo, kdo bi lahko tajil, da je bila dušam podeljena ta prirojena lastnost? Vse, kar poganjajo zunanje sile, je namreč neživo; kar pa je živo, se premika iz notranjega, lastnega vzgiba.To je prirojena lastnost in moč duše; če je izmed vseh stvari edina, ki ima v sebi gonilno silo, zagotovo ni bila rojena in je večna.

(29) Ti jo torej uri v najplemenitejših zaposlitvah! Najboljše so dejavnosti, ki zadevajo blagostanje domovine. Če jih bo duša opravljala in se urila v njih, bo hitreje priletela $v$ to bivališče, njen dom. To se bo zgodilo še prej, če se bo že takrat, ko bo zaprta v telesu, dvignila iz njega, opazovala zunanje pojave in se čimbolj ločila od njega. Tisti, ki so se predali telesnemu uživanju in so se mu tako rekoč ponudili za sužnje pod vplivom poželenj, ki služijo užitkom, so prekršili božje in človeške zakone; ${ }^{67}$ ko njihove duše zapustijo telesa, obletavajo zemljo in se v ta kraj vrnejo šele potem, ko so se mnogo stoletij mučno potikale naokoli ${ }^{6}{ }^{68}$

Izginil je, jaz pa sem se zdramil iz sna. ${ }^{69}$

66 Cicero se odkrito sklicuje na odlomek iz Platonovega Fajdra (Phaedr. 245c-246a), oziroma ga dejansko prevede. Isto besedilo najdemo v delu Tusculanae disputationes (Tusc 1.53-54), parafrazo pa tudi v razpravi De senectute (78).

67 Očiten napad na epikurejce, ki jim je užitek pomenil največjo dobrino.

68 Cicero v delu Tusculanae disputationes (Tusc. 1.43 isl.) razlaga, da duše tistih, ki se prepuščajo strastem, otežuje zemeljska navlaka, ki preprečuje, da bi se njihovo ognjeno bistvo hitreje dvigalo proti nebu. Cicero se očitno navezuje na odlomek iz Platonovega Fajdra (Phaedr. 248e-249a): grški filozof je mnenja, da se pot duše v nebo vleče deset tisoč let; le filozofi ga lahko dosežejo že po samo tri tisoč letih.

69 Solutus sum, dobesedno "me je spanec izpustil«; izraz se navezuje na izraz complexus iz prvega paragrafa, »me je objel«. 